\title{
A review of the South American monsoon history as recorded in stable isotopic proxies over the past two millennia
}

\author{
M. Vuille ${ }^{1}$, S. J. Burns ${ }^{2}$, B. L. Taylor ${ }^{2,3}$, F. W. Cruz ${ }^{4}$, B. W. Bird ${ }^{5}$, M. B. Abbott ${ }^{6}$, L. C. Kanner ${ }^{2,7}$, H. Cheng ${ }^{8,9}$, and \\ V. F. Novello 4 \\ ${ }^{1}$ Department of Atmospheric and Environmental Sciences, University at Albany, Albany, USA \\ ${ }^{2}$ Department of Geosciences, University of Massachusetts, Amherst, USA \\ ${ }^{3}$ Radioactive Waste Management Associates, Bellows Falls, USA \\ ${ }^{4}$ Instituto de Geosciencias, Universidade de Sao Paulo, Sao Paulo, Brazil \\ ${ }^{5}$ Department of Earth Sciences, Indiana University - Purdue University, Indianapolis, USA \\ ${ }^{6}$ Department of Geology and Planetary Science, University of Pittsburgh, Pittsburgh, USA \\ ${ }^{7}$ Department of Earth Sciences, University of Southern California, Los Angeles, USA \\ ${ }^{8}$ Institute of Global Environmental Change, Xi' an Jiatong University, Xi' an, China \\ ${ }^{9}$ Department of Geology \& Geophysics, University of Minnesota, Minneapolis, USA
}

Correspondence to: M. Vuille (mvuille@albany.edu)

Received: 10 February 2012 - Published in Clim. Past Discuss.: 27 February 2012

Revised: 2 July 2012 - Accepted: 6 August 2012 - Published: 23 August 2012

\begin{abstract}
We review the history of the South American summer monsoon (SASM) over the past $\sim 2000 \mathrm{yr}$ based on high-resolution stable isotope proxies from speleothems, ice cores and lake sediments. Our review is complemented by an analysis of an isotope-enabled atmospheric general circulation model (GCM) for the past 130 yr. Proxy records from the monsoon belt in the tropical Andes and SE Brazil show a very coherent behavior over the past 2 millennia with significant decadal to multidecadal variability superimposed on large excursions during three key periods: the Medieval Climate Anomaly (MCA), the Little Ice Age (LIA) and the current warm period (CWP). We interpret these three periods as times when the SASM's mean state was significantly weakened (MCA and CWP) and strengthened (LIA), respectively. During the LIA each of the proxy archives considered contains the most negative $\delta^{18} \mathrm{O}$ values recorded during the entire record length. On the other hand, the monsoon strength is currently rather weak in a 2000-yr historical perspective, rivaled only by the low intensity during the MCA. Our climatic interpretation of these archives is consistent with our isotope-based GCM analysis, which suggests that these sites are sensitive recorders of large-scale monsoon variations.

We hypothesize that these centennial-scale climate anomalies were at least partially driven by temperature changes in
\end{abstract}

the Northern Hemisphere and in particular over the North Atlantic, leading to a latitudinal displacement of the ITCZ and a change in monsoon intensity (amount of rainfall upstream over the Amazon Basin). This interpretation is supported by several independent records from different proxy archives and modeling studies. Although ENSO is the main forcing for $\delta^{18} \mathrm{O}$ variability over tropical South America on interannual time scales, our results suggest that its influence may be significantly modulated by North Atlantic climate variability on longer time scales.

Finally, our analyses indicate that isotopic proxies, because of their ability to integrate climatic information on large spatial scales, could complement more traditional proxies such as tree rings or documentary evidence. Future climate reconstruction efforts could potentially benefit from including isotopic proxies as large-scale predictors in order to better constrain past changes in the atmospheric circulation.

\section{Introduction}

Global monsoon systems are of great importance to society, delivering water for agriculture, hydropower production and a myriad of other socioeconomic activities. Monsoon 
variations are also responsible for droughts and famine or can lead to widespread flooding and damage to infrastructure. The South American summer monsoon (SASM) is one of the major monsoon systems in the Southern Hemisphere, yet it has received relatively little attention, due to the fact that it has only been considered a proper monsoon system for little more than a decade (Zhou and Lau, 1998). As a result the dynamics and spatiotemporal variability of the SASM are still poorly understood, although great strides are being made to better understand its sensitivity to various forcings such as sea surface temperatures (SST), vegetation or soil moisture and its interactions with other modes of variability such as the El Niño-Southern Oscillation (ENSO) or tropical Atlantic variability (e.g., Vera et al., 2006).

While we know fairly little about modern monsoon variability, the situation is even bleaker regarding variations in monsoon intensity during the recent past (e.g., the past 2 millennia). High-resolution climate reconstructions in South America have so far been limited to mid- and high latitudes, where proxies such as tree rings or historical documents that provide both high resolution and precise dating are abundant (e.g., Villalba et al., 2009; Neukom et al., 2010, 2011). In the tropics, such studies are still very rare (e.g., Ballantyne et al., 2011). Yet, recent studies suggest that the current monsoon characteristics on which society relies today have undergone considerable fluctuations in the past (e.g., Bird et al., 2011a). In addition, there is considerable concern that the SASM dynamics will be significantly affected by increasing greenhouse gas concentrations in the 21st century (Seth et al., 2010). Hence, there is an urgent need to better document and understand the causes of monsoon variations in response to natural forcings during the most recent past.

Stable water isotopic proxy records, predominantly derived from speleothems, have been used to document the past history of monsoon systems around the globe (Burns et al., 2002; Fleitmann et al., 2003; Wang et al., 2008; Zhang et al., 2008). Proxies that incorporate stable water isotopes from meteoric water may be ideally suited for this type of analysis, because isotopic fractionation is affected by several factors along the transport pathway from source to sink which lends itself well to use them as indicators of past changes in atmospheric circulation (e.g., Schmidt et al., 2007). Given the rapid emergence of new, high-resolution and precisely dated water isotope records from a variety of archives and regions within the South American monsoon belt, an opportunity presents itself to start filling the void in our understanding of past SASM variations.

Here we present a review of the available high-resolution isotopic records from ice cores, lake sediments and speleothems and discuss how these proxies could be combined to reconstruct the SASM history for the past 2 millennia in a dynamically meaningful and physically plausible way. We back up our interpretation of these records with an analysis from an isotope-enabled general circulation model for the past $134 \mathrm{yr}$. Section 2 gives an introduction to the
SASM and discusses some common misconceptions regarding its interactions with the Intertropical Convergence Zone (ITCZ). Section 3 reviews the current understanding of the climatic controls on stable water isotopes in the tropics and in the SASM region in particular. Section 4 presents the available high-resolution proxy records from the region dominated by SASM precipitation and gives an overview of both observational and model-simulated climate and stable isotope data used in this analysis. In Sect. 5 we discuss the various records and how they can be interpreted in terms of past monsoon variations in a way consistent with theoretical considerations and in line with our model simulations. We end with a short discussion and draw some final conclusions in Sect. 6.

\section{The South American summer monsoon (SASM)}

The SASM was first discussed in detail in a landmark paper by Zhou and Lau (1998), but several international programs under the CLIVAR-VAMOS umbrella have since made significant progress in understanding its dynamics and variability (e.g., Marengo et al., 2012a). The SASM shows a distinct seasonal cycle with an onset during October, a mature phase between December and February, and demise in April (e.g., Marengo et al., 2001; Raia and Cavalcanti, 2008). During the peak phase of the SASM, a zone of deep convection is established over the southern part of the Amazon Basin as indicated by the reduced outgoing longwave radiation (OLR), over the core monsoon region (Fig. 1a). The upper tropospheric circulation is dominated by the Bolivian High, an upper level anticyclone established as a wave response to latent heat release in the zone of deep convection (Lenters and Cook, 1997). The strong easterlies to the north of the anticyclone core are responsible for near-surface moisture flux into the subtropical and tropical Andes (Garreaud et al., 2003). During the demise phase between March and May, the monsoon progressively weakens and eventually disappears completely. During the dry winter season, the main zone of convective activity has withdrawn from the Southern Hemisphere and resides over Colombia, extending into the western Pacific and Central America (Fig. 1b).

On interannual time scales, the monsoon system is significantly influenced by other modes of variability, most notably ENSO (e.g., Paegle and Mo, 2002; Grimm, 2003, 2004) but also the Pacific Decadal Oscillation (PDO), tropical Atlantic variability, cold air incursions from the mid-latitudes and the Atlantic Multidecadal Oscillation (AMO) (Zhou and Lau, 2001; Marengo, 2004; Chiessi et al., 2009). As shown by Garreaud et al. (2009), the influence of ENSO varies slightly during the course of the year, but in general tropical South America tends to experience drier than normal conditions during El Niño, while conditions in mid-latitudes are anomalously humid. During La Niña events, the signal is essentially reversed. The PDO has a very similar fingerprint as ENSO, 
but the impacts on precipitation are generally weaker (Garreaud et al., 2009).

Little is known about how the SASM has varied in the past. To some extent, this is related to confusion in the paleoclimatic literature about the South American monsoon system and its relationship with the ITCZ, two systems that are still often used interchangeably when describing summer precipitation over the tropical continent. Yet, the monsoon system over tropical South America has spatiotemporal characteristics that are quite different from the maritime ITCZ, so it makes sense to draw a clear distinction between the two systems even on longer time scales. For one the ITCZ persists all year round, following the region of warmest SSTs, while the SASM is a seasonal phenomenon, with a well-established onset, mature phase and demise period. Furthermore, the ITCZ is strictly a Northern Hemisphere phenomenon and only extends into the Southern Hemisphere during extreme El Niño episodes in the eastern equatorial Pacific (e.g., Takahashi and Battisti, 2007). The SASM, on the other hand, protrudes far into the Southern Hemisphere during its mature phase in austral summer.

But there are also differences that are more relevant for paleoclimate research. The SASM is primarily sensitive to land-sea thermal gradients and therefore on orbital time scales responds quite sensitively to changes in insolation, as documented for example in Cruz et al. (2005a). The ITCZ, on the other hand, essentially follows the regions of warmest sea surface temperature and as such is very sensitive to meridional SST gradients. Modeling studies clearly document a southward latitudinal displacement of the ITCZ during periods of high latitude cooling in response to the enhanced need for northward heat transport in order to balance the greater cooling (e.g., Chiang and Bitz, 2005). To physically displace a monsoon system, on the other hand, is much more difficult to achieve, especially over South America where the spatial extent of the monsoon belt is fundamentally determined by land surface characteristics. The monsoon interacts with vegetation, soil moisture and is subject to interactions with cold air outbreaks from high latitudes (e.g., Li and Fu, 2006; Collini et al., 2008), but its spatial extent is ultimately the result of the shape of the continent and the topography of the Andes and the Brazilian Highlands. These topographic constraints are key elements that shape the Andean low-level jet, responsible for monsoon-related moisture flux toward southeastern South America. Since topography and morphology of the continent do not change on time scales relevant for our discussion, large-scale latitudinal monsoon shifts are much more difficult to attain than they are for the ITCZ over the oceans.

Nonetheless, as discussed in more detail in the following sections, the location of the ITCZ is of considerable importance for SASM intensity, given that moisture influx to the continent is closely tied to ITCZ dynamics.

\section{The climatic controls on stable water isotopes over tropical South America}

The isotopic composition of water vapor transported from the tropical Atlantic toward the interior of the South American continent during the SASM active season can, in its simplest form, be described by a simple Rayleigh distillation model, where condensation processes progressively remove water from the atmosphere through precipitation and runoff, leaving the remaining water vapor isotopically more and more depleted. In reality, some of the precipitation lost is reincorporated to the air mass through transpiration (a nonfractionating process) and evaporation (a fractionating process). As a result of these processes, water vapor is added back to the atmosphere that is relatively more enriched when compared with the surrounding atmospheric vapor, hence reducing the isotopic gradient across the continent (Salati et al., 1979; Victoria et al., 1991; Martinelli et al., 1996). Rayleigh fractionation also does not account for mixing of air masses with different isotopic compositions along the air mass trajectory. Nonetheless, isotopic variations are ultimately a reflection of the degree of rainout from the atmosphere, which led early studies to focus primarily on condensation temperature and the amount of precipitation at the site where $\delta^{18} \mathrm{O}$ is being recorded ("amount effect") (Dansgaard, 1964; Rozanski et al., 1992; Risi et al., 2008). Such relationships between $\delta^{18} \mathrm{O}$ in rain and snow and climate would potentially allow $\delta^{18} \mathrm{O}$ variations in geologic material to be used as a proxy for local climatic conditions at the sites where precipitation takes place. Observational evidence does indeed support the notion that the amount effect explains a significant fraction of isotopic variations on seasonal and interannual time scales (Hardy et al., 2003; Vuille et al., 2003a), although modeling studies suggest that this effect is strongest over eastern South America close to the moisture source and becomes progressively weaker inland and over western South America (Vimeux et al., 2005). This relationship is consistent with precipitation in the tropics being predominantly of convective nature, where condensation temperature is no longer the first-order control on the degree of distillation. Instead, the intensity of small-scale convective updrafts and rainout and thus amount of precipitation emerges as the primary control on the isotopic composition of precipitation. Recent studies, however, point out that much of the amount effect can be explained by subsequent re-evaporation of the falling rain and vapor recycling into the convective system (Risi et al., 2008).

A completely different interpretation of stable water isotopes in South American proxies emerged from early work on Andean ice cores. These records have traditionally been interpreted as recording temperature (e.g., Thompson et al., 2006). Indeed Thompson et al. (1995) suggested a significant cooling in the Andes during the Last Glacial Maximum (LGM) based on highly depleted $\delta^{18} \mathrm{O}$ observed in Andean ice cores. Pierrehumbert (1999) later pointed out that this interpretation would not necessarily require such a substantial 

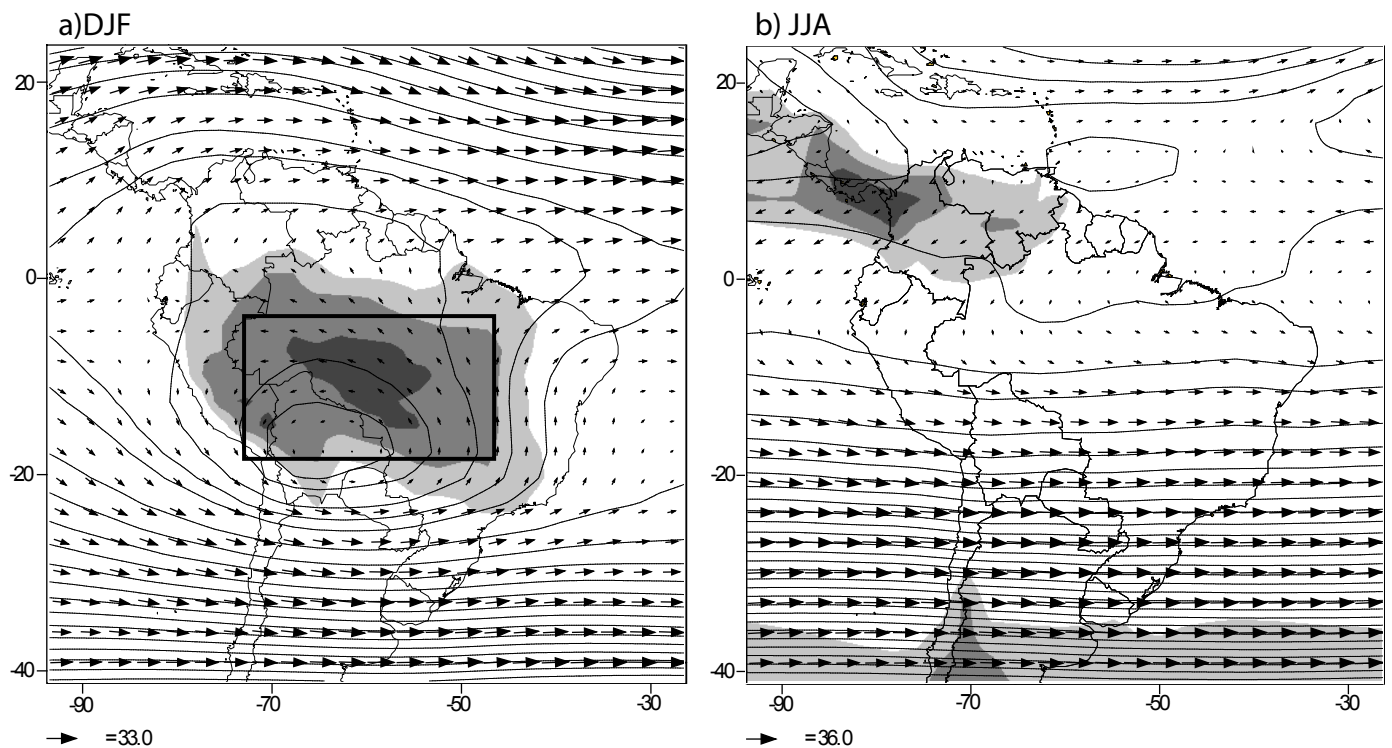

Fig. 1. Long-term mean $200 \mathrm{hPa}$ wind and geopotential height and outgoing long-wave radiation based on NCEP/NCAR reanalysis and NOAA-OLR data for (a) austral summer (December-February, DJF) and (b) winter (June-August, JJA). Contour interval is 25 gpm, 10 gpm above 12400 and $5 \mathrm{gpm}$ above 12430 . Light, medium, and dark shades indicate OLR values less than 225, 210, and 195 W m ${ }^{-2}$. Black rectangle in (a) denotes region of strongest convective activity during DJF used to create monsoon index $M$.

temperature drop, if the fraction of water vapor removed from the atmosphere during transport had increased during the LGM. Nonetheless, the interpretation of $\delta^{18} \mathrm{O}$ as a temperature proxy is inconsistent with a number of other lines of evidence. This interpretation does not hold on any observational time scales considered (Hardy et al., 2003; Vimeux et al., 2009), is in disagreement with model results (Vuille et al., 2003a; Vimeux et al., 2005), and is inconsistent with Holocene insolation forcing (Bird et al., 2011b) and the reconstructed temperature evolution based on other proxies (e.g., van Breukelen et al., 2008; Jomelli et al., 2011).

More recently, the realization that the stable water isotopic composition of an air mass is affected by processes that take place far upstream from the site of the proxy has lead to the concept of interpreting water isotopes as recorders of atmospheric circulation or modes of climate variability. In tropical South America, proxies within the SASM domain are now generally considered to reflect the degree of rainout, or the transport efficiency over the core monsoon region, thereby affecting the isotopic composition of the remaining water vapor and hence the isotopic signal of precipitation further downstream (Vuille and Werner, 2005; Sturm et al., 2007; Villacis et al., 2008). In this framework, isotopic proxy records are seen as indicators of monsoon intensity over the core region of convective activity, the Amazon Basin (e.g., Cruz et al., 2005a; Polissar et al., 2006; Bird et al., 2011b). This concept is supported by isotope-enabled modeling studies both in South America (Hoffmann et al., 2003; Vimeux et al., 2005; Vuille and Werner, 2005) and the Asian monsoon region (Vuille et al., 2005; Pausata et al., 2011). Given that the SASM is not an independent system, but is strongly influenced by other climate modes on interannual timescales, several studies have been able to document a strong remote influence of ENSO on Andean proxy records (e.g., Bradley et al., 2003; Vuille et al., 2003b;). Finally, changes in moisture source can also have a significant impact on the $\delta^{18} \mathrm{O}$ composition, which becomes an important factor to consider in regions where summer monsoon precipitation is competing with winter precipitation originating from mid-latitude disturbances (e.g., Cruz et al., 2005b). In such instances, changes in the $\delta^{18} \mathrm{O}$ may reflect changes in the relative contribution of the two sources to total precipitation, rather than changes in total rainfall amount or in the isotopic composition of precipitation from one region. While the monsoon precipitation is ultimately sourced from the tropical Atlantic, extra-tropical precipitation receives its moisture from midand high-latitude oceans.

\section{Data and methods}

\subsection{Paleoclimate proxy records}

The history of the South American summer monsoon through the Late Pleistocene and the Holocene has been derived primarily from speleothems. Several ice core records also cover the period since the Last Glacial Maximum (Thompson et al., 1995, 1998; Ramirez et al., 2003), but these records have traditionally been interpreted as recording temperature rather than changes in the SASM. Speleothems, on the other hand, have revealed insight into the sensitivity of the SASM to 
Table 1. High-resolution stable water isotope records in the South American monsoon domain.

\begin{tabular}{lllrrr}
\hline No. & Name & Proxy & Coordinates & Elevation & Reference \\
\hline 1 & Cascayunga cave & Speleothem calcite $\delta^{18} \mathrm{O}$ & $6.09^{\circ} \mathrm{S}, 77.23^{\circ} \mathrm{W}$ & $930 \mathrm{~m}$ & Reuter et al. (2009) \\
2 & Laguna Pumacocha & Lake sediment calcite $\delta^{18} \mathrm{O}$ & $10.70^{\circ} \mathrm{S}, 76.06^{\circ} \mathrm{W}$ & $4300 \mathrm{~m}$ & Bird et al. (2011a) \\
3 & Quelccaya Ice Cap & Ice core $\delta^{18} \mathrm{O}$ & $13.93^{\circ} \mathrm{S}, 70.83^{\circ} \mathrm{W}$ & $5670 \mathrm{~m}$ & Thompson et al. (1986) \\
4 & Cristal cave & Speleothem calcite $\delta^{18} \mathrm{O}$ & $24.58^{\circ} \mathrm{S}, 48.58^{\circ} \mathrm{W}$ & $130 \mathrm{~m}$ & Taylor $(2010)$ \\
5 & Huagapo cave & Speleothem calcite $\delta^{18} \mathrm{O}$ & $11.27^{\circ} \mathrm{S}, 75.79^{\circ} \mathrm{W}$ & $3550 \mathrm{~m}$ & Kanner et al. (2011) \\
6 & Diva de Maura and Torrinha cave & Speleothem calcite $\delta^{18} \mathrm{O}$ & $12.37^{\circ} \mathrm{S}, 41.57^{\circ} \mathrm{W}$ & $700 \mathrm{~m}$ & Novello et al. (2012) \\
\hline
\end{tabular}

insolation forcing (Cruz et al., 2005a, 2009a,b; Wang et al., 2006, 2007; van Breukelen et al., 2008), to abrupt changes in North Atlantic climate (Wang et al., 2004; Cruz et al., 2006; Cheng et al., 2009; Strikis et al., 2011) and its relationship with monsoon variations in the Northern Hemisphere (Wang et al., 2006). Lake records and paleo-shoreline deposits have also significantly advanced our understanding of changes in monsoon characteristics through the Holocene (Abbott et al., 2000, 2003; Seltzer et al., 2000; Baker et al., 2001, 2005; Wolfe et al., 2001; Fritz et al., 2006; Polissar et al., 2006; Ekdahl et al., 2008; Hernandez et al., 2008; Bird et al., 2011b; Placzek et al., 2011).

In conjunction, these records from the Andes, southeastern and northeastern Brazil provide clear evidence that the monsoon is highly sensitive to precessional forcing and responds with a strengthening during periods of increased Southern Hemisphere summer insolation. Gradually decreasing isotopic values from the Early to Late Holocene therefore document the progressive strengthening of the SASM over the Holocene. While many of these records extend all the way to the present, their resolution is insufficient to resolve subdecadal variability of the SASM over the past $2000 \mathrm{yr}$.

Here we instead focus on a set of archives, which, with the exception of the Quelccaya ice core, includes fairly new records from the regions influenced by summer monsoon precipitation. Table 1 summarizes these records, and Fig. 2 shows their location in relation to the amount of precipitation they receive today during the mature phase of the SASM in DJF. All these records are located within the monsoon belt and ideally suited to record past variations in monsoon intensity.

The Cascayunga speleothem $\delta^{18} \mathrm{O}$ record stems from a lowland cave to the east of the Andes in northern Peru and extends back to 1050 AD (Reuter et al., 2009). Laguna Pumacocha is a high-altitude lake in the central Peruvian Andes, which contains annually laminated sediments (varves) with seasonally varying deposition of biogenic material and authigenic lake calcite extending back over the past $2300 \mathrm{yr}$ (Bird et al., 2011a). The Quelccaya ice core record is the oldest of the four records considered and is based on $\delta^{18} \mathrm{O}$ of annually deposited ice layers extracted from the summit of the world's largest tropical ice cap in south-central Peru, extending back $1500 \mathrm{yr}$ (Thompson et al., 1986). The speleothem

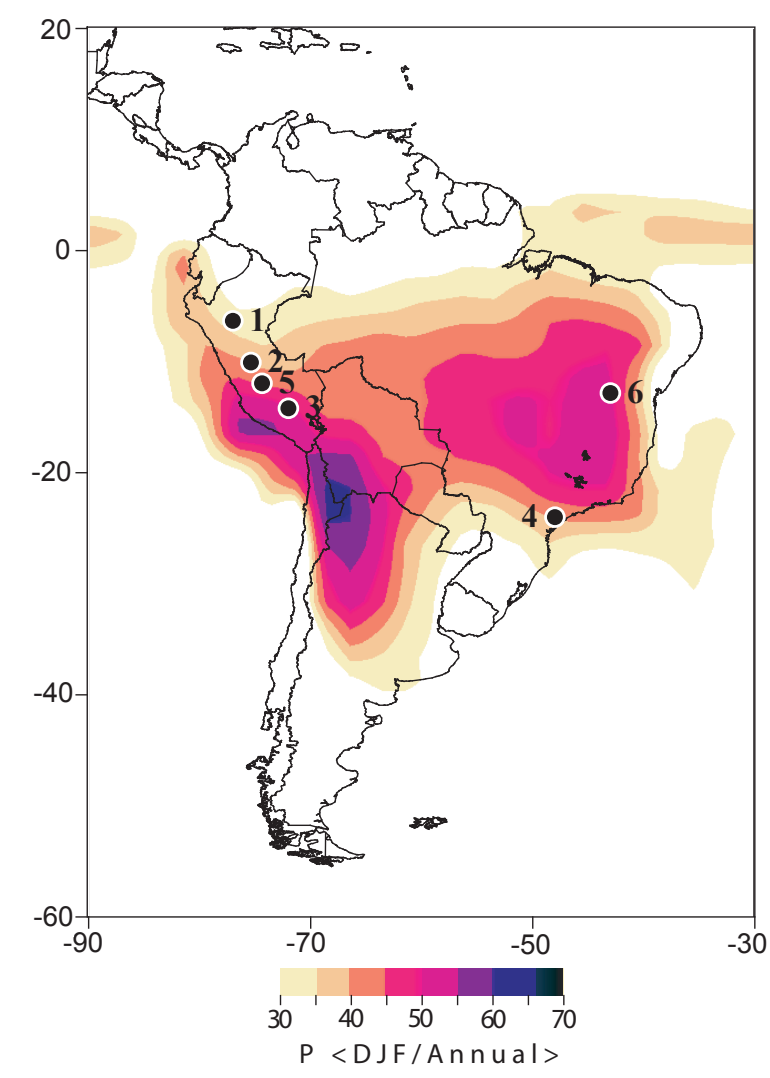

Fig. 2. Percentage of annual precipitation falling during the mature stage of the South American summer monsoon (DJF), based on CMAP data (1979-2004). Numbers indicate location of highresolution stable isotope records within the monsoon belt: 1: Cascayunga cave; 2: Laguna Pumacocha; 3: Quelccaya Ice Cap; 4: Cristal cave; 5: Huagapo cave; 6: Diva de Maura and Torrinha cave.

$\delta^{18} \mathrm{O}$ record from Cristal cave is yet unpublished (Taylor, 2010) and will be discussed and presented in greater detail elsewhere. It is derived from a cave in SE Brazil (see Table 1 and Fig. 2), extends back $4100 \mathrm{yr}$ and was sampled at a sub-decadal resolution. A total of $14 \mathrm{U} / \mathrm{Th}$ ages with analytical errors $(2 \sigma)$ averaging \pm 13 yr allow for a very precise age determination (Taylor, 2010). Here we focus exclusively on the last $2300 \mathrm{yr}$ and its comparison with the other 
isotopic records. Finally, it is worth noting that several additional high-resolution isotopic records that cover the past several millennia are currently in preparation or in press (Locations 5 and 6 in Figs. 2 and 4). These records (Diva de Maura and Torrinha cave in NE Brazil; Novello et al., 2012 and Huagapo cave in Peru; Kanner et al., 2011) will be discussed elsewhere, but it is interesting to point out that their location is also in the main monsoon belt (see Fig. 2 and Table 1), adding to the rapidly growing list of high-resolution isotopic records from this region.

\subsection{Observational data}

We use observational isotope data from the International Atomic Energy Agency-Global Network of Isotopes in Precipitation (IAEA-GNIP) database to characterize the relationship between stable isotopic variation and monsoon intensity over South America. Unfortunately, the available data are very sparse, contain a lot of gaps and are in most cases not available up to the present. Nonetheless, several stations contain more than $10 \mathrm{yr}$ worth of observations and these stations were retained in our analysis. More information on these data is available at http://www-naweb.iaea.org/ napc/ih/IHS_resources_gnip.html. To characterize the SASM strength in the observational record, we rely on National Centers for Environmental Prediction - National Center for Atmospheric Research (NCEP/NCAR) reanalysis data (Kalnay et al., 1996), National Oceanic and Atmospheric Administration (NOAA) outgoing longwave radiation (OLR) data (Liebmann and Smith, 1996), a commonly used proxy for precipitation in the tropics and on Climate Prediction Center Merged Analysis of Precipitation (CMAP) data (Xie and Arkin, 1997), a gridded data set based on a blend of satellite measurements and in-situ rain gauge observations.

\subsection{SWING model results from ECHAM-4}

Given that observational data are so limited in time and space, we make use of an isotope-enabled general circulation model from the Stable Water Isotope iNtercomparison Group (SWING)-I initiative. This initiative provides a suite of 134yr-long integrations based on atmospheric GCMs with isotopic tracers, forced with observed SST and sea-ice coverage between 1870 and 2003. We rely on the ECHAM-4 model, because this model has been more extensively tested over South America than the other available models (GISS ModelE and MUGCM), with very good results, both for present-day conditions (Hoffman et al., 2003; Vuille et al., 2003a,b; Vimeux et al., 2005; Vuille and Werner, 2005) as well as for the Mid-Holocene (Cruz et al., 2009a). More information on the SWING-I experiments can be found at http://www.bgc-jena.mpg.de/projects/SWING/.

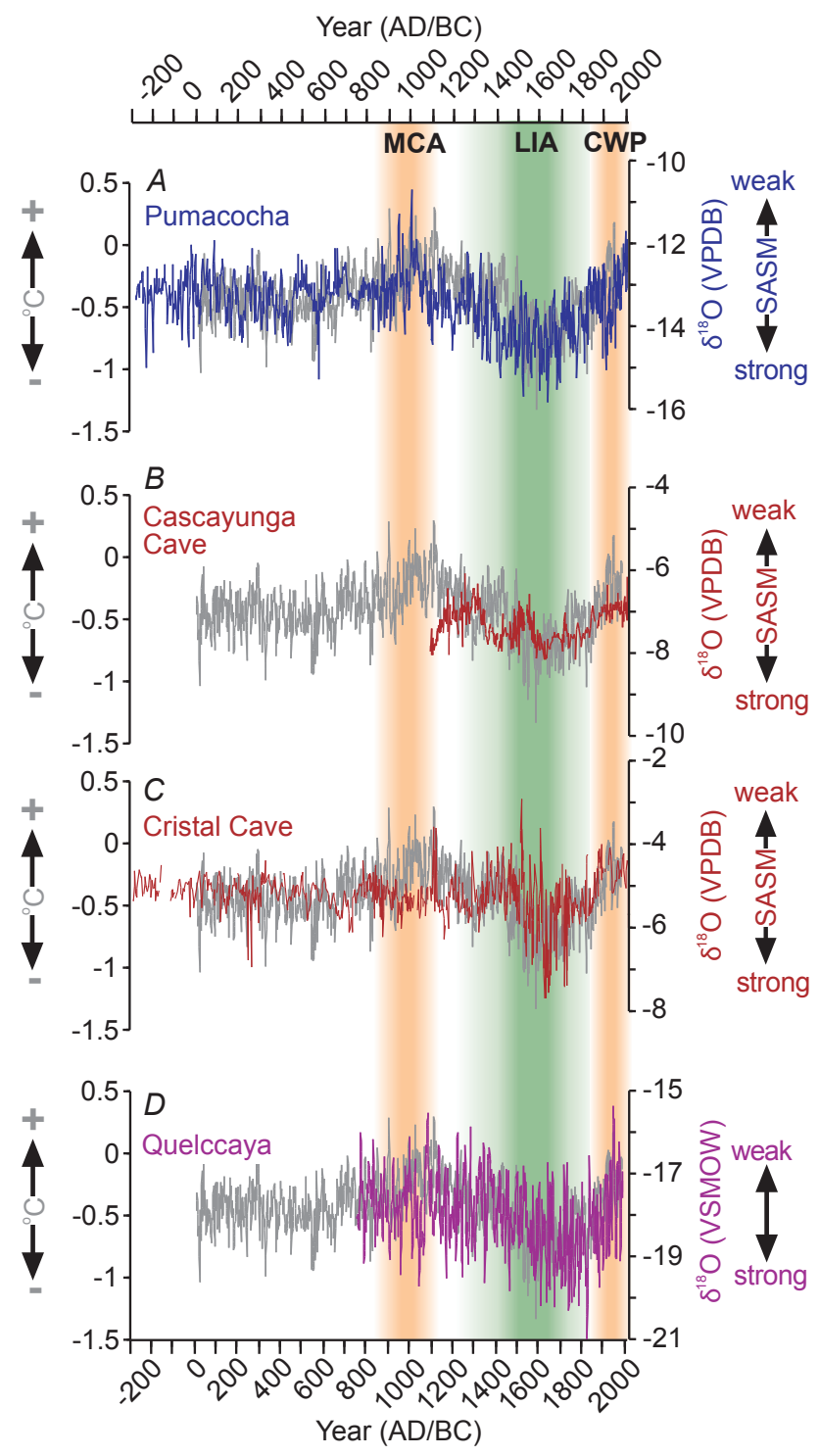

Fig. 3. (A) South American monsoon intensity changes over the past $2300 \mathrm{yr}$ as displayed in high-resolution stable isotopic records from (top to bottom) Pumacocha $\delta^{18} \mathrm{O}$ lake calcite; Cascayunga cave $\delta^{18} \mathrm{O}$ speleothem calcite, Cristal cave $\delta^{18} \mathrm{O}$ speleothem calcite and Quelccaya $\delta^{18} \mathrm{O}$ ice core. The Moberg et al. (2005) Northern Hemisphere temperature reconstruction is reproduced in each panel as a gray line for comparison.

\section{Results}

Figure 3 shows a comparison of the four high-resolution records over the past $\sim 2300$ yr. Bird et al. (2011a) already provided a detailed discussion of the comparison between the three Andean records Quelccaya, Pumacocha and Cascayunga, which we summarize briefly below. In addition, however, we demonstrate that this similarity extends into another region within the monsoon belt, southeastern Brazil, as evidenced by the Cristal cave record. 


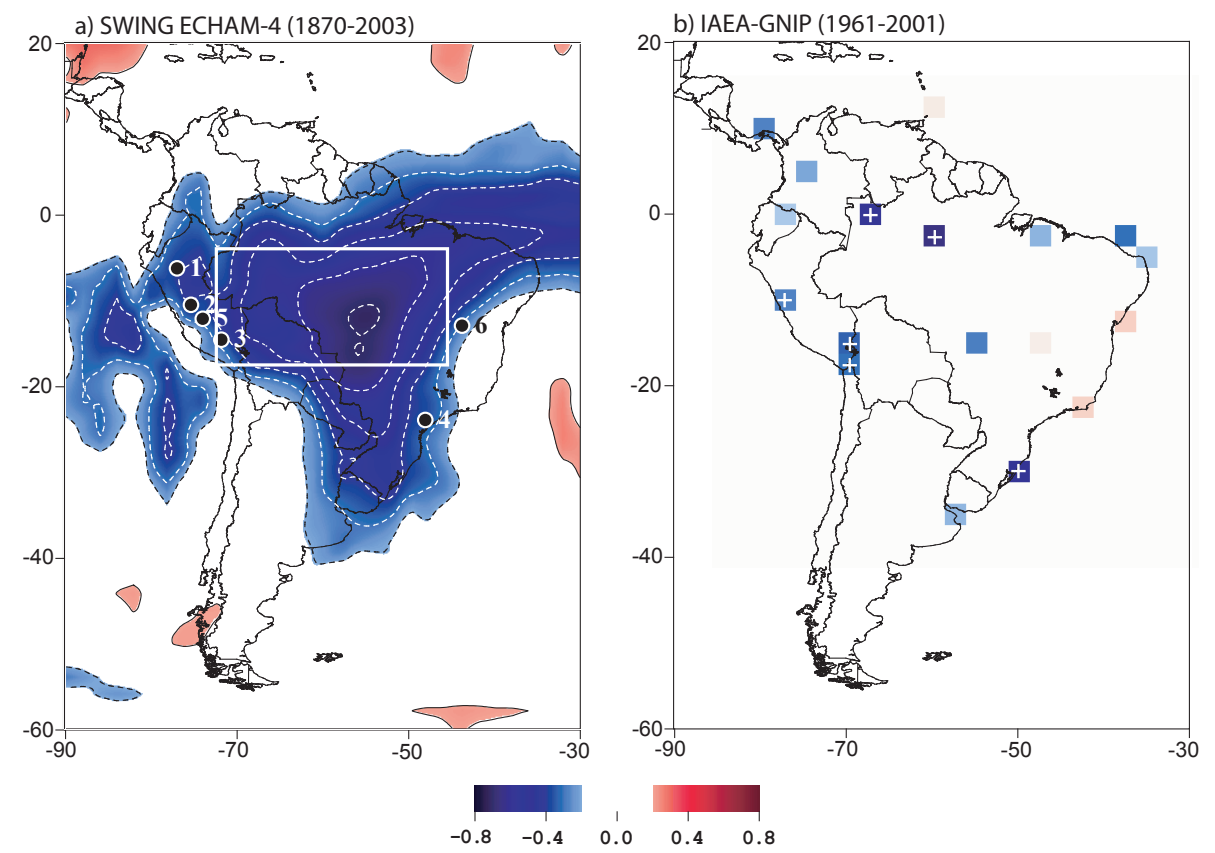

Fig. 4. (a) Spatial correlation of monsoon index $M$ (DJF precipitation averaged within white box) with precipitation-weighted DJF $\delta^{18} \mathrm{O}$ values throughout the South American monsoon domain in SWING simulation with ECHAM-4 (1870-2003). Only regions with significant correlation at $p<0.05$ are shaded. Contour intervals are 0.1 , with $-0.1,0$ and 0.1 contour lines omitted. (b) as in (a) but based on IAEAGNIP observations and ice core records from Huascarán, Quelccaya and Sajama correlated with monsoon index based on vertical wind shear as defined in Vuille and Werner (2005). Record lengths of individual observations vary, but all records contain at least 10 yr within period 1961-2001. Note that unlike in ((a) all correlations are shown but that significant correlations at $p<0.05$ are indicated with a white cross. Panel (b) is modified from Vuille and Werner (2005).

All four records are characterized by dominant centuryscale departures, superimposed upon strong decadal- to multidecadal variability. These century-scale mean-state changes include positive departures during the Medieval Climate Anomaly (MCA), strong negative anomalies during the Little Ice Age (LIA) and a significant positive trend over the past $\sim 100 \mathrm{yr}$ termed the current warm period (CWP) in Bird et al. (2011a). All records except for Cascayunga, which does not extend back that far, show positive departures during the MCA, although this period is not as pronounced at Quelccaya and occurs later and over a contracted time period in Cristal cave. During the LIA between $\sim 1600$ and $\sim 1820 \mathrm{AD}, \delta^{18} \mathrm{O}$ values are highly depleted and represent the most negative values over the entire record length in each of the four proxy time series. Again, the timing of the LIA onset is different between the sites with the northern records Pumacocha and Cascayunga showing a much earlier onset of the decrease in $\delta^{18} \mathrm{O}$ than the more southern records Quelccaya and Cristal cave. After $\sim 1850$ all records show a steep and continued increase of $\delta^{18} \mathrm{O}$ toward the present, with values as high as or higher than during the MCA.

To shed further light on the potential origins of these largescale perturbations that are broadly coherent between these diverse records, we make use of the SWING ECHAM-4 simulation. We first create a monsoon index $(M)$ to characterize the monsoon intensity during the mature phase of the SASM. Vuille and Werner (2005) discussed several possibilities of creating an interannual monsoon index. Here we use a very simple index, which is calculated as the seasonal average precipitation in the SWING model over the core region of convection $\left(5^{\circ} \mathrm{S}-17.5^{\circ} \mathrm{S} / 72.5^{\circ} \mathrm{W}-47.5^{\circ} \mathrm{W}\right.$; black and white rectangles in Figs. 1 and 4 respectively). We choose this index as it is easy to calculate in models and observations, a good proxy for monsoon intensity and it is directly related to stable isotopic variations as it is by definition factoring in the degree of rainout over the Amazon Basin. Hence, in our discussion the term, "monsoon intensity" specifically refers to the total precipitation amount in the core region of convective activity during the mature phase of the monsoon between December and February. Figure 4a shows the correlation of this monsoon index in DJF with contemporaneous $\delta^{18} \mathrm{O}$ variations elsewhere in South America. Not surprisingly, the correlations are most negative over the region used to define the index itself. Here the negative relationship can be interpreted as a simple "amount effect" as we are correlating precipitation intensity in the region defined by the rectangle with $\delta^{18} \mathrm{O}$ values in the same region. As is evident in Fig. 4a, however, there are large regions downstream of the core region of convection, extending across the entire southern and central tropical Andes and into southeastern South America and 
the South Atlantic Converge Zone (SACZ) region that also display significant negative correlations. In all these regions, which include all of our proxy sites (Fig. 4a), $\delta^{18} \mathrm{O}$ variations are significantly negatively related to precipitation over the southern Amazon Basin.

It is difficult to fully validate this type of model analysis with observational data given the paucity of information. In Fig. 4b we have reproduced a similar analysis by Vuille and Werner (2005) using observations and ice core data from three Andean sites (Quelccaya, Huascarán and Sajama) over the past few decades. Although the picture is patchy, and the monsoon index is based on zonal wind shear rather than precipitation amount, the result emerging from the limited observational evidence is clearly consistent with the model simulation, featuring significant negative correlations (indicated by a white cross) over the Amazon Basin, the tropical Andes and southeastern Brazil. It is also noteworthy that the model appears to correctly simulate the lack of significant correlations over central-eastern Brazil, a region influenced by the South Atlantic Anticyclone at that time of year.

In summary these analyses suggest that, at least on interannual time scales over the past $130 \mathrm{yr}$, there is indeed a common climate signal that is shared between all these sites in the monsoon belt related to the degree of rainout and hence monsoon intensity upstream. If this interpretation is applied to the isotopic records plotted in Fig. 3, it would suggest a significant weakening of monsoon intensity during the MCA and a dramatic strengthening of the SASM during the LIA period between $\sim 1600$ and 1820, unrivaled in the entire record. Similarly, the increase in $\delta^{18} \mathrm{O}$ over the last $\sim 100 \mathrm{yr}$ would indicate a long-term reduction in the intensity of the SASM, which today appears on par with conditions during the MCA.

\section{Discussion and conclusions}

In the modern climate, ENSO has a dominant influence on SASM variations and its isotopic signature (Vuille and Werner, 2005). ENSO signals have been identified in a number of high-resolution isotopic proxies from tropical South America (Bradley et al., 2003; Vuille et al., 2003b; Knuesel et al., 2005). Pacific SST reconstructions, however, point toward a La Niña-like state during the MCA and an El Niñolike state during the LIA (Cobb et al., 2003; Graham et al., 2007; Conroy et al., 2008; Mann et al., 2009), which is difficult to reconcile with the isotopic excursions observed in proxies from the monsoon belt. Several studies have suggested that some of the observed climate perturbations during this period may instead be related to persistent sea surface temperature anomalies (SSTA) in the North Atlantic sector. As already pointed out by Bird et al. (2011a) and highlighted in Fig. 3, there is indeed a remarkable correspondence between Northern Hemisphere temperature and the mean-state changes in the Andean isotopic records during the MCA, LIA and the CWP. This correspondence equally applies to the southeastern record from Cristal cave. This close correlation indicates that the SASM was exceptionally strong during the LIA, when Northern Hemisphere temperatures reached a $2000 \mathrm{yr}$ minimum. A weakening of the SASM, on the other hand, occurred during the MCA and the CWP with Northern Hemisphere temperatures at above average levels.

Several studies indeed indicate that SSTA in the North Atlantic during the MCA were unusually warm, akin to the positive phase of the AMO or the NAO (Feng et al., 2008; Trouet et al., 2009). In addition, there are indications that the AMO may indeed significantly affect the SASM on multidecadal time scales, leading to reduced monsoon intensity when the AMO is in its positive phase and the ITCZ is withdrawn northward (Chiessi et al., 2009; Strikis et al., 2011; Bird et al., 2011a). While this hypothesis is difficult to verify given the lack of long observational records in tropical South America, it is consistent with the notion that the mean location of the ITCZ acts as an important modulator of the SASM intensity on multidecadal to centennial time scales through its sensitivity to Northern Hemisphere temperature. Modeling studies have in fact documented that a cooling in the Northern Hemisphere, such as observed during the LIA, leads to a southward displacement of the ITCZ, which can be interpreted as a thermodynamic adjustment to allow for enhanced northward heat transport required to balance the high latitude cooling (Zhang and Delworth, 2005; Broccoli et al., 2006). Proxy evidence also documents such a southward shift of the ITCZ during the LIA, both in the Pacific and the Atlantic sector (Haug et al., 2001; Sachs et al., 2009). As discussed in Sect. 2, the ITCZ and the SASM are distinct systems and the monsoon is not as easily displaced latitudinally as the ITCZ. But since the ITCZ serves as the major moisture flux conduit fueling convective activity over the SASM region, the location and strength of the ITCZ do matter greatly (e.g., Garcia and Kayano, 2010). A more southerly position leads to enhanced moisture flux into the tropical continent and enhanced convective activity over the main monsoon domain (e.g., Marengo et al., 2012b). A more northerly position, on the other hand, is conducive to enhanced subsidence over the Amazon Basin, effectively suppressing convection, as evidenced, for example, during the Amazon drought in 2005 (Marengo et al., 2008; Zeng et al., 2008) and 2010 (Lewis et al., 2011). This ITCZ-SASM relationship is consistent with the apparent intensification of the monsoon system during cold periods in the Northern Hemisphere as documented in Fig. 3. However, while the ITCZ is displaced, the changes in the SASM likely represent a strengthening and weakening over roughly the same domain, rather than a large-scale southward shift.

Our results, combining high-resolution proxy data with isotope-enabled modeling experiments, provide strong support for the notion that these isotopic proxy records, located within the South American monsoon belt, all record variations in SASM intensity upstream rather than just local climatic conditions at the site. The close correspondence 
between the four records is particularly notable, given that they represent very different archives and environments. The fact that $\delta^{18} \mathrm{O}$ records several thousand kilometers apart, extracted from ice cores and carbonate from lakes and cave formations at both high-elevation alpine environments and tropical lowlands over western and southeastern South America, display such similar behavior over the past 2 millennia is remarkable. It is hard to reconcile with the notion that these records would record primarily local climatic conditions. Instead, the four archives have recorded changes that were regional-continental in scale with broadly similar timing, direction and magnitude (Bird et al., 2011a). All four sites receive a large fraction of their annual precipitation total during the summer monsoon season, and they all share a common source, the tropical Atlantic. Water vapor arrives at all four sites fairly depleted and has undergone vigorous convective activity and rainout upstream over the southern Amazon Basin. It is this signal, indicative of the strength of the South American monsoon, that all these records have in common. While Bird et al. (2011a) already pointed out the similarities between the three Andean sites, we here extend this discussion by showing that the strengthening of the SASM during the LIA and its weakening during the MCA and the CWP were not limited to the Andes but a response observed over a broader region of the monsoon belt. In this context it is worth noting that new high-resolution isotopic records from the SASM belt, currently in preparation or in press (e.g., Kanner et al., 2011; Novello et al., 2012), also reveal significant departures during the LIA, although over NE Brazil the signal is antiphased when compared to the other sites (Novello et al., 2012), consistent with observations during the Holocene (Cruz et al., 2009a). Overall, our preliminary analysis of the available high-resolution isotopic proxy records suggests that the SASM responded in a very sensitive way to changes in Northern Hemisphere temperature. In particular, the dominant influence of ENSO appears to be strongly modulated by the latitudinal position of the ITCZ on multidecadal to centennial time scales.

Our review documents that the SASM has undergone significant perturbations over the past 2 millennia and that the monsoon strength is currently rather weak in a 2000 -yr historical perspective. Given the concern about future abrupt changes in monsoon precipitation due to increasing greenhouse gas concentrations, it is crucial that we learn more about the sensitivity of the SASM to changes in radiative forcing as they occurred during the MCA and the LIA. Stable isotopic proxies are a key element to achieve this goal as they are sensitive recorders of large-scale monsoon variations. The isotopic response to upstream monsoon variability is maintained along an air mass trajectory, regardless of whether the local precipitation at the site where isotopes are ultimately measured is highly correlated with the precipitation signal over the Amazon Basin or not. Therefore, the isotopic response to a climatic perturbation tends to be regionally much more coherent than the precipitation response itself, which can be significantly altered by topography and microclimatic effects (Schmidt et al., 2007). Hence, isotopic proxy records are very powerful at capturing regional- to large-scale climate but they are not the most useful to reconstruct local climatic conditions as is traditionally done in multi-proxy reconstructions based on tree rings or historical archives. Yet, traditional approaches of reconstructing regional precipitation or temperature patterns in space and time often lack the dynamic constraints imposed by the atmospheric circulation. Stable isotope records offer the potential to put these reconstructions to the test by providing clear guidelines on past changes in large-scale atmospheric circulation and variations of key components of the climate system such as the SASM. Future regional climate reconstructions should therefore make an effort to incorporate both types of proxies - those suitable as indicator of local climate as well as those that provide constraints on the large-scale circulation.

Acknowledgements. We wish to thank Martin Werner for making the ECHAM-4 SWING model results available. This study was supported by the National Science Foundation P2C2 (award AGS-1003690 to MV and ATM-1003466 to SJB) and Earth System History program (award to MBA) and by the Fundação de Amparo a Pesquisa do Estado de São Paulo, Brazil (award to FWC).

Edited by: T. Kiefer

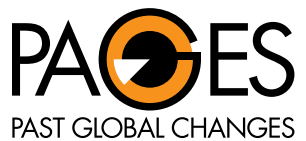

The publication of this article was sponsored by PAGES.

\section{References}

Abbott, M. A., Wolfe, B. B., Aravena, R., Wolfe, A., and Seltzer, G.: Holocene hydrological reconstructions from stable isotopes and paleolimnology, Cordillera Real Bolivia, Quaternary Sci. Rev., 19, 1801-1820, 2000.

Abbott, M. A., Wolfe, B. B., Wolfe, A. P., Seltzer, G. O., Aravena, R., Mark, B. G., Polissar, P. J., Rodbell, D. T., Rowe, H. D., and Vuille, M.: Holocene paleohydrology and glacial history of the central Andes using multiproxy lake sediment studies, Palaeogeogr. Palaeocl., 194, 123-138, 2003.

Baker, P. A., Seltzer, G. O., Fritz, S. C., Dunbar, R. B., Grove, M. J., Tapia, P. M., Cross, S. L., Rowe, H. D., and Broda, J. P.: The history of South American tropical precipitation for the past 25,000 years, Science, 291, 640-643, doi:10.1126/science.291.5504.640, 2001.

Baker, P. A., Fritz, S. C., Garland, J., and Ekdahl, E.: Holocene hydrologic variation at Lake Titicaca, Bolivia/Peru, and its relationship to North Atlantic climate variation, J. Quatern. Sci., 20, 655-662, doi:10.1002/jqs.987, 2005.

Ballantyne, A. P., Baker, P. A., Chambers, J. Q., Villalba, R., and Argollo, J.: Regional differences in South American monsoon precipitation inferred from the growth and isotopic composition of tropical trees, Earth Interact., 15, 1-35, 2011. 
Bird, B. W., Abbott, M. B., Vuille, M., Rodbell, D. T., Rosenmeier, M. F., and Stansell, N. D.: A 2300-year-long annually resolved record of the South American summer monsoon from the Peruvian Andes, P. Natl. Acad. Sci., 108, 8583-8588, 2011a.

Bird, B. W., Abbott, M. B., Rodbell, D. T., and Vuille, M.: Holocene tropical South American hydroclimate revealed from a decadally resolved lake sediment $\delta^{18} \mathrm{O}$ record, Earth Planet. Sc. Lett., 310, 192-202, 2011b.

Bradley, R. S., Vuille, M., Hardy, D. R., and Thompson, L. G.: Low latitude ice cores record Pacific sea surface temperatures, Geophys. Res. Lett., 30, 1174, doi:10.1029/2002GL016546, 2003.

Broccoli, A. J., Dahl, K. A., and Stouffer, R.J.: Response of the ITCZ to northern hemisphere cooling, Geophys. Res. Lett., 33, L01702, doi:10.1029/2005GL024546, 2006.

Burns, S. J., Fleitmann, D., Mudelsee, M., Neff, U., Matter, A., and Mangini, A.: A 780-year annually resolved record of Indian Ocean monsoon precipitation from a speleothem from south Oman, J. Geophys. Res., 107, 4434, doi:10.1029/2001JD001281, 2002.

Cheng, H., Fleitmann, D., Edwards, L. R., Wang, X., Cruz, F. W., Auler, A. S., Mangini, A., Wang, Y., Kong, X., Burns, S. J., and Matter, A.: Timing and structure of the $8.2 \mathrm{kyr}$ B.P. event inferred from $\delta^{18} \mathrm{O}$ records of stalagmites from China, Oman, and Brazil, Geology, 37, 1007-1010, doi:10.1130/G30126A.1, 2009.

Chiang, J. C. H. and Bitz, C. M.: Influence of high latitude ice cover on the marine Intertropical Convergence Zone, Clim. Dynam., 25, 477-496, doi:10.1007/s00382-005-0040-5, 2005.

Chiessi, C., Mulitza, S., Paetzold, J., Wefer, G., and Marengo, J.: Possible impact of the Atlantic Multidecadal Oscillation on the South American summer monsoon, Geophys. Res. Lett., 36, L21707, doi:10.1029/2009GL039914, 2009.

Cobb, K., Charles, C. D., Cheng, H., and Edwards, R. L.: El Niño/Southern Oscillation and tropical Pacific climate during the last millennium, Nature, 424, 271-276, 2003.

Collini, E., Berbery, E., Barros, V., and Pyle, M.: How does soil moisture influence the early stages of the South American monsoon?, J. Climate, 21, 195-213, 2008.

Conroy, J. L., Overpeck, J. T., Cole, J. E., Shanahan, T. M., and Steinitz-Kannan, M.: Holocene changes in eastern tropical Pacific climate inferred from a Galápagos lake sediment record, Quaternary Sci. Rev., 27, 1166-1180, 2008.

Cruz Jr., F. W., Burns, S. J., Karmann, I., Sharp, W. D., Vuille, M., Cardoso, A. O., Ferrari, J. A., Silva Dias, P. L., and Viana Jr., O.: Insolation-driven changes in atmospheric circulation over the past 116,000 years in subtropical Brazil, Nature, 434, 63-66, $2005 a$.

Cruz Jr. F. W., Karmann, I., Viana Jr., O., Burns, S. J., Ferrari, J. A., Vuille, M., Moreira, M. Z., and Sial, A. N.: Stable isotope study of cave percolation waters in subtropical Brazil: implications for paleoclimate inferences from speleothems, Chem. Geol., 220, 245-262, 2005b.

Cruz Jr., F. W., Burns, S. J., Karmann, I., Sharp, W. D., and Vuille, M.: Reconstruction of regional atmospheric circulation features during the Late Pleistocene in subtropical Brazil from oxygen isotope composition of speleothems, Earth Planet. Sc. Lett., 248, 494-506, 2006.

Cruz Jr., F. W., Vuille, M., Burns, S. J., Wang, X., Cheng, H., Werner, M., Edwards, R. L., Karmann, I., Auler, A. S., and Nguyen, H.: Orbitally driven east-west anti-phasing of South American precipitation, Nat. Geosci., 2, 210-214, doi:10.1038/NGEO444, 2009a.

Cruz Jr., F. W., Wang, X., Auler, A., Vuille, M., Burns, S. J., Edwards, R. L., Karmann, I., and Cheng, H.: Orbital and millennialscale precipitation changes in Brazil from speleothem records, in: Past climate variability in South America and surrounding regions, edited by: Vimeux, F., Sylvestre, F., and Khodri, M., Developments in Paleoenvironmental Research Series, 14, Springer Publishing, 29-60, 2009b.

Dansgaard, W.: Stable isotopes in precipitation, Tellus, 16, 436468, doi:10.1111/j.2153-3490.1964.tb00181.x, 1964.

Ekdahl, E. J., Fritz, S. C., Baker, P. A., Risgby, C. A., and Coley, K.: Holocene multidecadal-to millennial-scale hydrologic variability on the South America Altiplano, Holocene, 18, 867-876, doi:10.1177/0959683608093524, 2008.

Feng, S., Oglesby, R. J., Rowe, C. M., Loope, D. B., and Hu, Q.: Atlantic and Pacific SST influences on Medieval drought in North America simulated by the Community Atmospheric Model, J. Geophys. Res., 113, D11101, doi:10.1029/2007JD009347, 2008.

Fleitmann, D., Burns, S. J., Mudelsee, M., Neff, U., Kramers, J., Mangini, A., and Matter, A.: Holocene forcing of the Indian Monsoon recorded in a stalagmite from southern Oman, Science, 300, 1737-1739, 2003.

Fritz, S. C., Baker, P. A., Tapia, P., and Garland, J.: Spatial and temporal variation in cores from Lake Titicaca, Bolivia/Peru during the last 13,000 years, Quatern. Int., 158, 23-29, doi:10.1016/j.quaint.2006.05.014, 2006.

Garcia, S. and Kayano, M.: Some evidence on the relationship between the South American monsoon and the Atlantic ITCZ, Theor. Appl. Climatol., 99, 29-38, 2010.

Garreaud, R., Vuille, M., and Clement, A.: The climate of the Altiplano: Observed current conditions and mechanisms of past changes, Palaeogeogr. Palaeocl., 194, 5-22, 2003.

Garreaud, R. D., Vuille, M., Compagnucci, R., and Marengo, J.: Present-day South American climate, Palaeogeogr. Palaeocl., 281, 180-195, 2009.

Graham, N. E., Hughes, M. K., Ammann, C., Cobb, K. M., Hoerling, M. P., Kennett, D. J., Kennett, J. P., Rein, B., Stott, L., Wigand, P. E., and Xu, T.: Tropical Pacific-Mid-latitude teleconnections during medieval times, Climatic Change, 81, 241-285, 2007.

Grimm, A. M.: The El Niño impact on the summer monsoon in Brazil: Regional processes versus remote influences, J. Climate, 16, 263-280, 2003.

Grimm, A. M.: How do la Niña events disturb the summer monsoon system in Brazil?, Clim. Dynam., 22, 123-138, 2004.

Hardy, D. R., Vuille, M., and Bradley, R. S.: Variability of snow accumulation and isotopic composition on Nevado Sajama, Bolivia, J. Geophys. Res., 108, 4693, doi:10.1029/2003JD003623, 2003.

Haug, G. H., Hughen, K., Sigman, D. M., Peterson, L. C., and Rohl, U.: Southward migration of the intertropical convergence zone through the Holocene, Science, 293, 1304-1308, 2001.

Hernandez, A., Bao, R., Giralt, S., Leng, M. J., Barker, P. A., Saez, A., Pueyo, J. J., Moreno, A., Valero-Garces, B., and Sloane, H. J.: The palaeohydrological evolution of Lago Chungara (Andean Altiplano, northern Chile) during the Lateglacial and early Holocene using oxygen isotopes in diatom silica, J. Quaternary Sci., 23, 351-363, 2008. 
Hoffmann, G., Ramirez, E., Taupin, J. D., Francou, B., Ribstein, P., Delmas, R., Duerr, H., Gallaire, R., Simoes, J., Schotterer, U., Stievenard, M., and Werner, M.: Coherent isotope history of Andean ice cores over the last century, Geophys. Res. Lett., 30, 1179, doi:10.1029/2002GL014870, 2003.

Jomelli, V., Khodri, M., Favier, V., Brunstein, D., Ledru, M.-P., Wagnon, P., Blard, P.-H., Sicart, J.-E., Braucher, R., Grancher, D., Bourlès, D., Braconnot, P., and Vuille, M.: Irregular tropical glacier retreat over the Holocene driven by progressive warming, Nature, 474, 196-199, 2011.

Kalnay, E., Kanamitsu, M., Kistler, R., Collins, W., Deaven, D., Gandin, L., Iredell, M., Saha, S., White, G., Woollen, J., Zhu, Y., Chelliah, M., Ebisuzaki, W., Higgins, W., Janowiak, J., Mo, K. C., Ropelewski, C., Wang, J., Leetmaa, A., Reynolds, R., Jenne, R., and Joseph, D.: The NCEP/NCAR 40-Year Reanalysis Project, B. Am. Meteorol. Soc., 77, 437-471, 1996.

Kanner, L., Burns, S. J., Vuille, M., Cheng, H., and Edwards, R. L.: Modern influences on simulated Andean rainfall $\delta^{18} \mathrm{O}$ and application to a Holocene speleothem record, Abstract American Geophysical Union Fall Meeting, PP24B-03, San Francisco, 2011.

Knuesel, S., Bruetsch, S., Henderson, K. A., Palmer, A. S., and Schwikowski, M.: ENSO signals of the twentieth century in an ice core from Nevado Illimani, Bolivia, J. Geophys. Res., 110, D01102, doi:10.1029/2004JD005420, 2005.

Lenters, J. D. and Cook, K. H.: On the origin of the Bolivian High and related circulation features of the South American climate, J. Atmos. Sci., 54, 656-677, 1997.

Lewis, S. L., Brando, P. M., Phillips, O. L., van der Heijden, G. M. F., and Nepstad, D.: The 2010 Amazon drought, Science, 331, $554,2011$.

$\mathrm{Li}, \mathrm{W}$. and Fu, R.: Influence of cold air intrusions on the wet season onset over Amazonia, J. Climate, 19, 257-275, 2006.

Liebmann, B. and Smith, C. A.: Description of a complete (interpolated) Outgoing Longwave Radiation dataset, B. Am. Meteorol. Soc., 77, 1275-1277, 1996.

Mann, M. E., Zhang, Z., Rutherford, S., Bradley, R. S., Hughes, M. K., Shindell, D., Ammann, C., Falugevi, G., and Ni, F.: Global signatures and dynamical origins of the "Little Ice Age" and "Medieval Climate Anomaly", Science, 326, 1256-1260, 2009.

Marengo, J. A.: Interdecadal variability and trends of rainfall across the Amazon basin, Theor. Appl. Climatol., 78, 79-96, 2004.

Marengo, J. A., Liebmann, B., Kousky, V. E., Filizola, N. P., and Wainer, I. C.: Onset and end of the rainy season in the Brazilian Amazon basin, J. Climate, 14, 833-852, 2001.

Marengo, J. A., Nobre, C. A., Tomasella, J., Oyama, M. D., De Oliveira, G. S., De Oliveira, R., Camargo, H., Alves, L. M., and Brown, I. F.: The drought of Amazonia in 2005, J. Climate, 21, 495-516, 2008.

Marengo, J. A., Liebmann, B., Grimm, A. M., Misra, V., Silva Dias, P. L., Cavalcanti, I. F. A., Carvalho, L. M. V., Berbery, E. H., Ambrizzi, T., Vera, C. S., Saulo, A. C., Nogues-Paegle, J., Zipser, E., Seth, A., and Alves, L. M.: Recent developments on the South American monsoon system, Int. J. Climatol., 32, 1-21, 2012a.

Marengo, J. A., Tomasella, J., Soares, W. R., Alves, L. M., and Nobre, C. A.: Extreme climatic events in the Amazon basin - Climatological and hydrological context of recent floods, Theor. Appl. Climatol., 107, 73-85, 2012b.
Martinelli, L. A., Victoria, R. L., Sternberg, L. S. L., Ribeiro, A., and Moreira, M. Z.: Using stable isotopes to determine sources of evaporated water to the atmosphere in the Amazon basin, J. Hydrol., 183, 191-204, 1996.

Moberg, A., Sonechkin, D. M., Holmgren, K., Datsenko, N. M., and Karlen, W.: Highly variable northern hemisphere temperatures reconstructed from low- and high-resolution proxy data, Nature, 433, 613-617, 2005.

Neukom, R., Luterbacher, J., Villalba, R., Kuettel, M., Frank, D., Jones, P. D., Grosjean, M., Esper, J., Lopez, L., and Wanner, H.: Multi-centennial summer and winter precipitation variability in southern South America, Geophys. Res. Lett., 37, L14708, doi:10.1029/2010GL043680, 2010.

Neukom, R., Luterbacher, J., Villalba, R., Kuettel, M., Frank, D., Jones, P. D., Grosjean, M., Wanner, H., Aravena, J.-C., Black, D. E., Christie, D. A., D’Arrigo, R., Lara, A., Morales, M., SolizGamboa, C., Srur, A., Urrutia, R., and von Gunten, L.: Multiproxy summer and winter surface air temperature field reconstructions for southern South America covering the past centuries, Clim. Dynam., 37, 35-51, 2011.

Novello, V. F., Cruz, F. W., Karmann, I., Burns, S. J., Stríkis, N. M., Vuille, M., Cheng, H., Edwards, R. L., Barreto, E. A. S., and Frigo, E.: Multidecadal climate variability in Brazil Nordeste during the last 3000 years based on speleothem isotope records, Geophys. Res. Lett., in preparation, 2012.

Paegle, J. N. and Mo, K.-C.: Linkages between summer rainfall variability over South America and sea surface temperature anomalies, J. Climate, 15, 1389-1407, 2002.

Pausata, F., Battisti, D. S., Nisancioglu, K. H., and Bitz, C. M.: Chinese stalagmite $\delta^{18} \mathrm{O}$ controlled by changes in the Indian monsoon during a simulated Heinrich event, Nat. Geosci., 4, 474480, 2011.

Pierrehumbert, R. T.: Huascaran $\delta^{18} \mathrm{O}$ as an indicator of tropical climate during the Last Glacial Maximum, Geophys. Res. Lett., 26, 1345-1348, 1999.

Placzek, C., Quade, J., and Patchett, P. J.: Isotopic tracers of paleohydrologic change in large lakes of the Bolivian Altiplano, Quaternary Res., 75, 231-244, 2011.

Polissar, P. J., Abbott, M. B., Shemesh, A., Wolfe, A. P., and Bradley, R. S.: Holocene hydrologic balance of tropical South America from oxygen isotopes of lake sediment opal, Venezuelan Andes, Earth Planet. Sc. Lett., 242, 375-389, 2006.

Raia, A. and Cavalcanti, I. F. D. A.: The life cycle of the South American monsoon system, J. Climate, 21, 6227-6246, 2008.

Ramirez, E., Hoffmann, G., Taupin, J. D., Francou, B., Ribstein, P., Caillon, N., Ferron, F. A., Landais, A., Petit, J. R., Pouyaud, B., Schotterer, U., Simoes, J. C., and Stievenard, M.: A new deep ice core from Nevado Illimani (6350 m), Earth Planet. Sc. Lett., 212, 337-350, 2003.

Reuter, J., Stott, L., Khider, D., Sinha, A., Cheng, H., and Edwards, R. L.: A new perspective on the hydroclimate variability in northern South America during the Little Ice Age, Geophys. Res. Lett., 36, L21706, doi:10.1029/2009GL041051, 2009.

Risi, C., Bony, S., and Vimeux, F.: Influence of convective processes on the isotopic composition $\left(\delta^{18} \mathrm{O}\right.$ and $\left.\delta \mathrm{D}\right)$ of precipitation and water vapor in the tropics: 2. Physical interpretation of the amount effect, J. Geophys. Res., 113, D19306, doi:10.1029/2008JD009943, 2008. 
Rozanski, K., Araguás-Araguás, L., and Gonfiantini, R.: Relation between long-term trends of oxygen-18 isotope composition of precipitation and climate, Science, 258, 981-985, 1992.

Sachs, J. P., Sachse, D., Smittenberg, R. H., Zhang, Z., Battisti, D. S., and Golubic, S.: Southward movement of the Pacific intertropical convergence zone AD 1400-1850, Nat. Geosci., 2, 519-525, 2009.

Salati, E., Dall'Olio, A., Matsui, E., and Gat, J. R.: Recycling of water in the Amazon basin: an isotopic study, Water Resour. Res., 15, 1250-1258, 1979.

Schmidt, G., LeGrande, A., and Hoffmann, G.: Water isotope expressions of intrinsic and forced variability in a coupled ocean-atmosphere model, J. Geophys. Res., 112, D10103, doi:10.1029/2006JD007781, 2007.

Seltzer, G., Rodbell, D., and Burns, S.: Isotopic evidence for late quaternary climatic change in tropical South America, Geology, 28, 35-38, 2000.

Seth, A., Rojas, M., and Rauscher, S. A.: CMIP3 projected changes in the annual cycle of the South American monsoon, Climatic Change, 98, 331-357, 2010.

Strikis, N. M., Cruz Jr., F. W., Cheng, H., Karmann, I., Edwards, R. L., Vuille, M., Wang, X., de Paula, M. S., Novello, V. F., and Auler, A. S.: Abrupt variations in South American monsoon rainfall during the Holocene based on a speleothem record from central-eastern Brazil, Geology, 39, 1075-1078, 2011.

Sturm, C., Vimeux, F., and Krinner, G.: Intraseasonal variability in South America recorded in stable water isotopes, J. Geophys. Res., 112, D20118, doi:10.1029/2006JD008298, 2007.

Takahashi, K. and Battisti, D. S.: Processes controlling the mean tropical Pacific precipitation pattern, Part I: The Andes and the eastern Pacific ITCZ, J. Climate, 20, 3434-3451, 2007.

Taylor, B. L.: A speleothems-based high resolution reconstruction of climate in southeastern Brazil over the past 4,100 years, M.S. thesis, University of Massachusetts, 2010.

Thompson, L. G., Mosley-Thompson, E., Dansgaard, W., and Grootes, P. M.: The Little Ice Age as recorded in the stratigraphy of the tropical Quelccaya Ice Cap, Science, 234, 361-364, 1986.

Thompson, L. G., Mosley-Thompson, E., Davis, M. E., Lin, P.-N., Henderson, K. A., Cole-Dai, J., Bolzan, J. F., and Liu, K.-B.: Late Glacial stage and Holocene tropical ice core records from Huascaran, Peru, Science, 269, 46-50, 1995.

Thompson, L. G., Davis, M. E., Mosley-Thompson, E., Sowers, T. A., Henderson, K. A., Zagorodnov, V. S., Lin, P.-N., Mikhalenko, V. N., Campen, R. K., Bolzan, J. F., Cole-Dai, J., and Francou, B.: A 25,000-year tropical climate history from Bolivian ice cores, Science, 282, 1858-1864, 1998.

Thompson, L. G., Mosley-Thompson, E., Brecher, H., Davis, M., Leon, B., Les, D., Lin, P.-N., Mashiotta, T., and Mountain, K.: Abrupt tropical climate change: Past and present, P. Natl. Acad. Sci., doi:10.1073/pnas.0603900103, 2006.

Trouet, V., Esper, J., Graham, N. E., Baker, A., Scourse, J. D., and Frank, D. C.: Persistent positive North Atlantic Oscillation mode dominated the Medieval climate anomaly, Science, 324, 78-80, 2009.

Van Breukelen, M. R., Vonhof, H. B., Hellstrom, J. C., Wester, W. C. G., and Kroon, D.: Fossil dripwater in stalagmites reveals Holocene temperature and rainfall variation in Amazonia, Earth Planet. Sc. Lett., 275, 54-60, 2008.
Vera, C., Baez, J., Douglas, M., Emmanuel, C. B., Marengo, J., Meitin, J., Nicolini, M., Nogues-Paegle, J., Paegle, J., Penalba, O., Salio, P., Saulo, C., Silva Dias, M. A., Silva Dias, P., and Zipser, E.: The South American low-level jet experiment, B. Am. Meteorol. Soc., 87, 63-77, 2006.

Victoria, R. L., Martinelli, L. A., Mortatti, J., and Richey, J.: Mechanisms of water recycling in the Amazon basin: Isotopic insights, Ambio, 20, 384-387, 1991.

Villacis, M., Vimeux, F., and Taupin, J. D.: Analysis of the climate controls on the isotopic composition of precipitation $\left(\delta^{18} \mathrm{O}\right)$ at Nuevo Rocafuerte, $74.5^{\circ} \mathrm{W}, 0.9^{\circ} \mathrm{S}, 250 \mathrm{~m}$, Ecuador, Comptes Rendus Geosci., 340, 1-9, 2008.

Villalba, R., Grosjean, M., and Kiefer, T.: Long-term multiproxy climate reconstructions and dynamics in South America (LOTRED-SA): State of the art and perspectives, Palaeogeogr. Palaeocl., 281, 175-179, 2009.

Vimeux, F., Gallaire, R., Bony, S., Hoffmann, G., and Chiang, J. C. $H$.: What are the climate controls on $\delta \mathrm{D}$ in precipitation in the Zongo Valley (Bolivia)? Implications for the Illimani ice core interpretation, Earth Planet. Sc. Lett., 240, 205-220, 2005.

Vimeux, F., Ginot, P., Schwikowski, M., Vuille, M., Hoffmann, G., Thompson, L. G., and Schotterer, U.: Climate variability during the last 1000 years inferred from Andean ice cores: a review of recent results, Palaeogeogr. Palaeocl., 281, 229-241, 2009.

Vuille, M. and Werner, M.: Stable isotopes in precipitation recording South American summer monsoon and ENSO variability - observations and model results, Clim. Dynam., 25, 401-413, doi:10.1007/s00382-005-0049-9, 2005.

Vuille, M., Bradley, R. S., Werner, M., Healy, R., and Keimig, F.: Modeling $\delta^{18} \mathrm{O}$ in precipitation over the tropical Americas: 1. Interannual variability and climatic controls, J. Geophys. Res., 108, 4174, doi:10.1029/2001JD002038, 2003a.

Vuille, M., Bradley, R. S., Healy, R., Werner, M., Hardy, D. R., Thompson, L. G., and Keimig, F.: Modeling $\delta^{18} \mathrm{O}$ in precipitation over the tropical Americas: 2. Simulation of the stable isotope signal in Andean ice cores, J. Geophys. Res., 108, 4175, doi:10.1029/2001JD002039, 2003b.

Vuille, M., Werner, M., Bradley, R. S., and Keimig, F.: Stable isotopes in precipitation in the Asian monsoon region, J. Geophys. Res., 110, D23108, doi:10.1029/2005JD006022, 2005.

Wang, X., Auler, A. S., Edwards, R. L., Cheng, H., Cristalli, P. S., Smart, P. L., Richards, D. A., and Shen, C.-C.: Wet periods in northeastern Brazil over the past $210 \mathrm{kyr}$ linked to distant climate anomalies, Nature, 432, 740-743, 2004.

Wang, X., Auler, A. S., Edwards, R. L., Cheng, H., Ito, E., and Solheid, M.: Interhemispheric anti-phasing of rainfall during the last glacial period, Quaternary Sci. Rev., 25, 3391-3403, 2006.

Wang, X., Auler, A. S., Edwards, R. L., Cheng, H., Ito, E., Wang, Y., Kong, X., and Solheid, M.: Millennial-scale precipitation changes in southern Brazil over the past 90,000 years, Geophys. Res. Lett., 34, L23701, doi:10.1029/2007GL031149, 2007.

Wang, Y., Cheng, H., Edwards, L. R., Kong, X., Shao, X., Chen, S., Wu, J., Jiang, X., Wang, X., and An, Z.: Millennial and orbital-scale changes in the East Asian monsoon over the past 224,000 years, Nature, 451, 1090-1093, 2008.

Wolfe, B. B., Aravena, R., Abbott, M. B., Seltzer, G. O., and Gibson, J. J.: Reconstruction of paleohydrology and paleohumidity from oxygen isotope records in the Bolivian Andes, Paleogeogr. Palaeocl., 176, 177-192, 2001. 
Xie, P. and Arkin, P. A.: Global Precipitation: A 17-year monthly analysis based on gauge observations, satellite estimates, and numerical model outputs, B. Am. Meteorol. Soc., 78, 2539-2558, 1997.

Zeng, N., Yoon, J.-H., Marengo, J. A., Subramaniam, A., Nobre, C. A., Mariotti, A., and Neelin, J. D.: Causes and impacts of the 2005 Amazon drought, Environ. Res. Lett., 3, 014002, doi:10.1088/1748-9326/3/1/014002, 2008.

Zhang, P., Cheng, H., Edwards, R. L., Chen, F., Wang, Y., Yang, X., Liu, J., Tan, M., Wang, X., Liu, J., An, C., Dai, Z., Zhou, J., Zhang, D., Jia, J., Jin, L., and Johnson, K.: A test of climate, sun and culture relationships from an 1810-yr Chinese cave record, Science, 322, 940-942, 2008.
Zhang, R. and Delworth, T. L.: Simulated tropical response to a substantial weakening of the Atlantic thermohaline circulation, J. Climate, 18, 1853-1860, 2005.

Zhou, J. and Lau, K.-M.: Does a monsoon climate exist over South America?, J. Climate, 11, 1020-1040, 1998.

Zhou, J. and Lau, K.-M.: Principal modes of interannual and decadal variability of summer rainfall over South America, Int. J. Climatol., 21, 1623-1644, 2001. 